\title{
Chinese Economic Growth: Implications for Brazilian Conservation Policies
}

\author{
Marcel Serra Coelho*, Fernando Moura Resende \& Geraldo Wilson Fernandes
}

Evolutionary Ecology \& Biodiversity, Departament of General Biology, Institute of Biological Sciences, Federal University of Minas Gerais - UFMG, Belo Horizonte, MG, Brazil

One of the simplest ways to summarize contemporary economic dynamics, although also more symptomatic, is the Circular Flow Theory. This is where companies co-opt in the market the factors of production - land, labor and capital - supplied by families who then receive their respective incomes. The companies, disposing of the factors of production, generate goods and services in exchange for revenue. The goods and services, in turn, are used by families who have their own expenses, thus closing the cycle (Daly \& Farley 2004). The circular flow theory was very useful in summarizing the economic process up to the first half of the twentieth century, when the abundance of natural resources, as well as the enormous ability to metabolize waste, ignored the absolute dependence of our economy on the environment. The world, still sparsely populated, wore this direct relationship between capital and labor, the most relevant variables in stimulating and maintaining the heated and rising economic flow. However, as a result of population growth and the need for continued economic growth, pressure on natural resources has increased exponentially in recent decades. The environment, once seen as unlimited, is now a source of concern and a threat to the continual growth of economic flows (Costanza 2008).

Besides the increasing pressure on natural resources as a result of a population explosion, and the need for growth of economic flows inherent to the development model, the world has witnessed profound changes in the last ten years, with direct impacts on the Brazilian economy (Daly \& Farley 2004). What stands out among these changes is the entrance of China to the World Trade Organization (WTO) in December 2001. With a population above 1.4 billion people, and with a stimulus for development and economic growth never seen before in modern history, China has altered the

*Send correspondence to: Marcel S. Coelho Evolutionary Ecology \& Biodiversity, DBG, ICB,

Federal University of Minas Gerais - UFMG, CEP 30161-970, Belo Horizonte, MG, Brazil

E-mail: marcel.s.coelho@gmail.com global economic geometry (WBG 2012). With a reserve of workers able to work for lower wages compared to the world's largest economies, coupled with flexible labor legislation, China attracted companies and investment from around the world, optimizing its industrialization process (WBG 2012). In 2010, China was already second in the world economy with a Gross Domestic Product (GDP) of \$ 5.9 billion, as well as being the country with the highest growth rate worldwide. Simultaneously with the industrialization process, China also initiated a process of high investment in infrastructure associated with a still novice urbanization process. China, which is still a rural country, is seeing a strong rise in urbanization rates (Figure 1f). From this theoretical framework emerges a corollary: since China is concentrating its economic activities on industrial products and its population is moving towards urban centers, the demand for primary products is increasing exponentially, impacting the economies of countries directly tied to the export of these products, such as Brazil (Dong 2003; Liu \& Diamond 2005; Grumbine 2007).

After China's entrance to the World Trade Organization (WTO), the Brazilian economy responded symptomatically to Chinese demands. The export volume of Brazilian primary products (e.g. Iron, Petroleum, Soya) increased exponentially after 2002 (Figure 1a). Simultaneous with Brazilian export increases, the prices of commodities have been significantly high in the last ten years, a consequence of the prodigious Chinese consumer market favoring the Brazilian economy (Figure 1b, c). Thus, China has become Brazil's principal trading partner, overtaking the United States (Figure 1e). This economically favorable environment has led to atypical growth in the Brazilian economy (Figure 1d). Faced with projections that the economic phenomena of the last ten years will be maintained and strengthened in the years to come, there is a need to analyze the environmental impacts of this process in order to guide Brazilian conservation policies towards preventative actions (Dong 2003). 

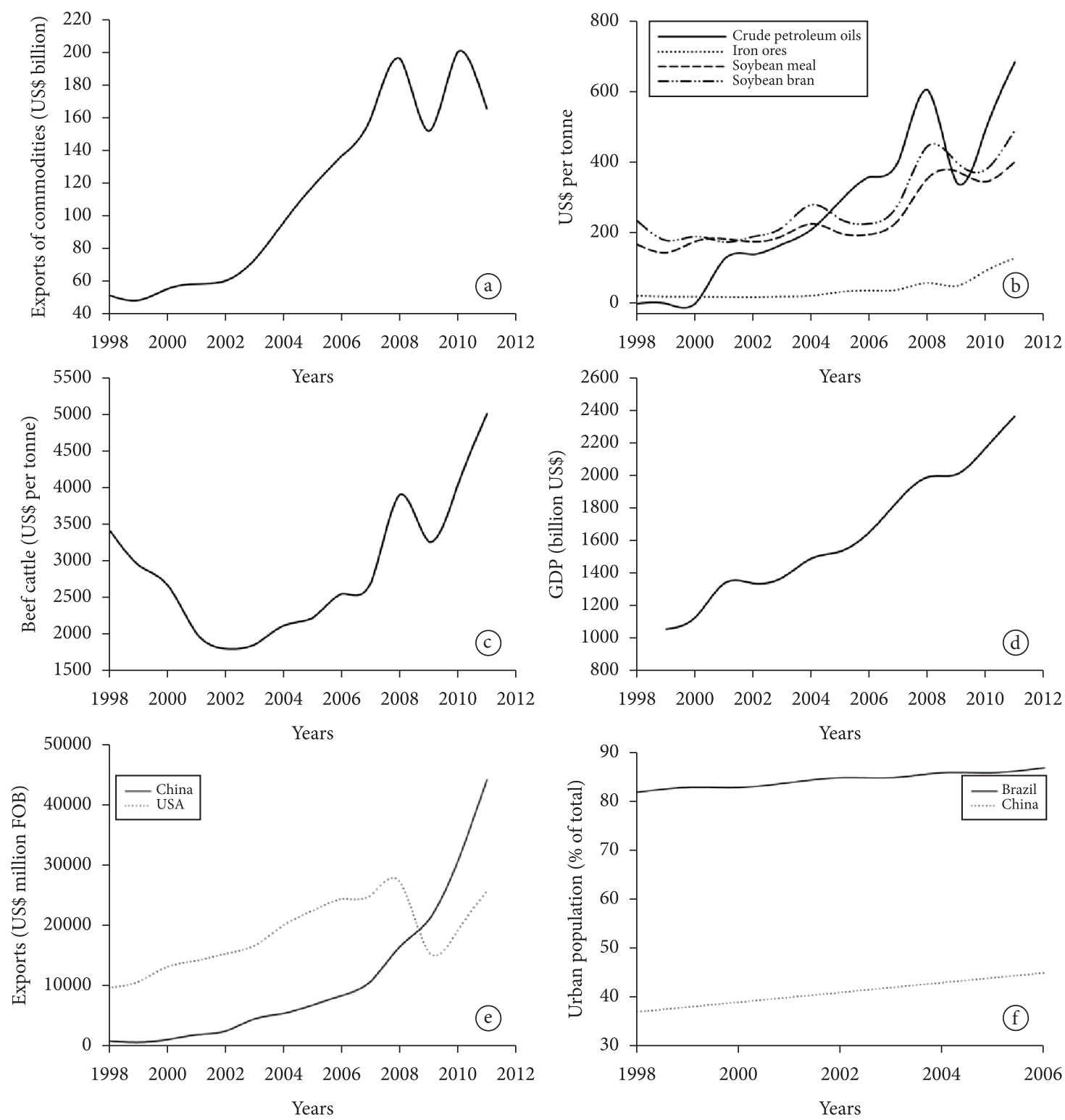

Figure 1. a) Export value of Brazilian commodities (raw sugar, refined sugar, ethanol, raw coffee beans, fresh beef, fresh chicken meat, fresh pork, crude oil, tobacco leaves, iron ore, cellulose, raw aluminum, soybean meal, soybean bran, crude soybean oil, orange juice) (Brasil 2012); b) Price variation of commodities selected in the international market (crude oil, iron ore, soybean meal, soybean bran) (Brasil 2012); c) Price variation of beef in the international market (Brasil 2012); d) Variation of Brazil's Gross Domestic Product (WBG 2012); e) Total exports from Brazil to China and the United States (Brasil 2012); f) Urban population (\% of total) of Brazil and China (WBG 2012).

\section{Implications for Brazilian Conservation Policies}

Propelled by primary product exports and increased rates of direct investment, Brazil initiated a growth acceleration process, culminating in a government project launched in January 2007 and branded with the same name (Programa de Aceleração de Crescimento - PAC: Growth Acceleration Program). This project encompasses investment policies in areas considered strategic for development, such as infrastructure, transportation and energy generation. At the same time, agribusiness companies strengthened, intensifying their activities through the expansion of agricultural boundaries. Predictably, in a country where development is initially based on the exploitation of primary products, environmental impacts and conflicts have intensified (Liu \& Diamond 2005).

This process is enabling investment growth in infrastructure, generating employment, inserting thousands of people into the consumer market and reducing regional inequalities by means of construction and expansion of railroads, shipyards and ports. Investments in energy generation are also being made, contributing to the growth of the Brazilian economy. Thus, hydroelectric ventures are conducted in 
remote regions of high biological and social importance (WBG 2012). Nevertheless, this is a global development model primarily designed and implemented in nations with diametrically opposite characteristics to those of Brazil. Besides its unique and diverse biological complexity (considered the most mega-diverse country in the world), Brazil is also a country with social diversity that is highly complex, sheltering different traditional communities (e.g. quilombolas, indigenous, ribeirinhos, sertanejos, caiçaras) (Lewinsohn \& Prado 2006; Oliveira et al. 2009). Therefore, a suitable legislation and legal system was implemented to safeguard this diversity. Rigid legislation imposes restrictions on the execution of large projects associated with the recent Brazilian stimulus toward growth, such as the hydroelectric dam on the Madeira River and the Belo Monte hydroelectric dam on the Xingú River.

However, along with policy development, also taking shape was the need to relax environmental legislation so that infrastructure works and energy generation projects would be viable, as well as the expansion of agricultural boundaries and maintenance of existing ventures. Simultaneous to the most ambitious development process ever conducted in Brazil after the first half of the twentieth century (PAC), a movement to modernize environmental legislation began. The first symbolic act in this process was the division of the "Instituto Brasileiro do Meio Ambiente e dos Recursos Naturais Renováveis" (IBAMA) [Brazilian Institute of Environment and Renewable Natural Resources], conducted by means of the Provisional Measure no 366 on 26 Abril 2007, by no accident the year that PAC was launched. With this division, the "Instituto Chico Mendes de Conservação da Biodiversidade" [Chico Mendes Institute for Biodiversity Conservation] was established to oversee the management of Conservation Units, leaving the IBAMA in charge of federal environmental enforcement and environmental licensing. Thus, the clearance process for ventures considered strategic for the development of the country became expedited. Another symbolic act was the reform of the Brazilian Forest Code, which among other accomplishments, now allows for degraded areas to be recomposed with non-native plants. It has also reduced the legal requirements for nascent recovery and eliminated the need for reforestation on legal reserves deforested before 2008 on properties of up to four fiscal modules. In addition, isolated acts, both at federal and state levels, have also reinforced this trend. The example of the provisional measure 558 excluded many $\mathrm{km}^{2}$ of Conservation Units, allowing for the establishment of large ventures, especially hydroelectric projects in the northern region of the country. In the state of Minas Gerais, the state bill 4057/09 sought to amend the state law 17353 in order to classify the Deciduous Seasonal Rainforests in northern Minas Gerais as vegetation that is no longer associated to the Atlantic Rainforest, but to the Caatingas area. This generated an expansion of agribusiness, leading to the clearing of $70 \%$ of the phytophysiognomy (Espírito-Santo et al. 2009).
Brazil is following a development paradigm based on economic growth. There are many questions about the sustainability of this development model, which is being systematically carried out, more so since the 80 s (Daly \& Farley 2004; Ropke 2004). Despite the important advances in technology that modern science has achieved, we cannot reach the required reusable energy levels nor the acceptable rates of product recycling derived from ore to maintain the social metabolism of modern civilization, let alone to support its growth. Thus, economic growth is dependent on the use of unsubstitutable products. A great example of this process is China, a country that has been making record investments in green technology; however, it has surpassed the United States as the largest emitter of $\mathrm{CO}_{2}$ (WBG 2012). At the same, the major international forums are seeking a better definition for green economy or a better way to grow sustainably. Other forms of development are being ignored, except those under the umbrella of growth (UNCSD 2012).

\section{Conclusion}

The current model of development, not only in Brazil but also throughout the world, is environmentally unsustainable. The alternatives considered in international forums do not question the model of development via economic growth, but rather delegate the technical solutions to the hope of a long future for humanity (UNCSD 2012). While benefitting from an international crisis, Brazil is facing the possibility of remedying basic social deficits and emerging as a power with significant international influence, supporting its development at the cost of expansion of agricultural boundaries and dilapidation of its biological and mineral heritage. Despite the environment being a problem of civilization - and it should be treated as such in international multilateral forums - serious research more strongly conducted after the 80 s, and criticisms of the prevailing model, must be given the opportunity to create concrete alternatives for environmental and economic problems (Daly \& Farley 2004; Ropke 2004). Brazil will witness an intensification of pressures on its biological, social and mineral heritage in the coming years as a result of demand for Chinese primary products (Dong 2003). Thus, it is also important that conservation biologists do not perceive the question simply from the perspective of seeking technical and palliative solutions. They must also consider other forms of development so that, when these solutions enter the agenda for multilateral discussions, they will be ready to contribute to the transition process. We believe it is possible to reconcile conservation with development. What does not seem possible is the viability of conservation policies with a paradigm of unlimited economic growth.

\section{Acknowledgements}

We would like to thank PhD. JAF Diniz-Filho, for considering our Forum proposal. Also thanks to MSc. G. A. A. Coelho, 
Analyst for the Central Bank of Brazil, for guidance in relation to the primary data used in this study and $\mathrm{PhD}$. R. L. do Monte Neto, for support and helpful comments.

\section{References}

Brasil. Ministério do Desenvolvimento Indústria e Comércio - MDIC. 2012. Balança comercial mensal. Available from: <http://www.mdic.gov.br/sitio/interna/ interna.php?area $=5 \&$ menu $=1161>$.

Costanza R, 2008. Stewardship for a "full" world. Current history, 107:30-35.

Daly HE \& Farley J, 2004. Ecological Economics: Principles and Aplications. Washington: Island Press.

Dong LZ, 2003. An econometric study on China's economy, energy and environment to the year 2030 . Energy Policy, 31:1137-1150. http://dx.doi.org/10.1016/ S0301-4215(02)00219-7

Espírito-Santo MM et al., 2009. Sustainanility of tropical dry forests: two case studies in southeastern and central Brazil. Forest Ecology and Management, 258:922-930. http://dx.doi. org/10.1007/s11258-009-9580-9
Grumbine RE, 2007. China's Emergence and the Prospects for Global Sustainability. BioScience, 53:249-255. http://dx.doi. org/10.1641/B570308

Lewinsohn T \& Prado PI 2006. How many species are there in Brazil? Conservation Biology, 19:619-624. http://dx.doi. org/10.1111/j.1523-1739.2005.00680.x

Liu J \& Diamond J. 2005. China's environment in a globalizing world how China and the rest of the world affect each other. Nature, 435:1179-1186. http://dx.doi.org/10.1038/4351179a

Oliveira FC et al. 2009. Avanços nas pesquisas etnobotânicas no Brasil. Acta Botanica Brasílica, 23:590-605. http://dx.doi. org/10.1590/S0102-33062009000200031

Ropke I, 2004. The early history of modern ecological economics. Ecological Economics, 50:293-314. http://dx.doi.org/10.1016/j. ecolecon.2004.02.012

The World Bank - WBG, 2012. Data. Available from: <http:// data.worldbank.org/>.

United Nations Conference on Sustainable Development - UNCSD, 2012. The future we want. Available from: <http://www.uncsd2012.org/content/ documents/727The\%20Future\%20We\%20Want\%2019\%20 June\%201230pm.pdf $>$.

Received: July 2012

First Decision: January 2013

Accepted: February 2013 